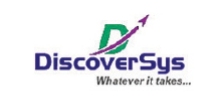

Published by DiscoverSys

\section{The relationship between body image and tea drinking habits with anemia among adolescent girls in Badung District, Bali, Indonesia}

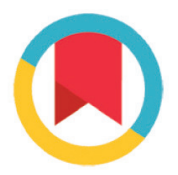

CrossMark

\author{
Kadek Agus Dwija Putra, ${ }^{1 *}$ Putu Cintya Denny Yuliyatni, ${ }^{2}$ Ni Ketut Sutiari ${ }^{2}$
}

\begin{abstract}
Background and purpose: The prevalence of anemia among adolescent girls in Indonesia remains high. Poor nutrition is a risk factor of anemia among adolescent girls, which is likely related to food intake restrictions to achieve a desired body shape (body image), and the habit of drinking tea while eating which can affect the absorption of iron. This study aims to determine the relationship between anemia with body image perception and tea drinking habits among adolescent girls.

Methods: This study used a cross-sectional design carried out from March-May 2018, involving girls aged 15-18 years at high schools in Badung District. Two schools were selected from 44 high schools, then a sample of 106 students were selected by systematic random sampling. Data collected included hemoglobin levels measured with hematology autoanalyzer, nutritional status with anthropometric measurements, and data on socio-demographics, socio-economics, tea drinking and eating habits, menstrual pattern, helminthiasis, knowledge and perception of body image with face-to-face individual interviews. Data were analyzed using

the Chi square test for bivariate analysis, and multivariate using logistic regression

Results: The prevalence of anemia (hemoglobin $<12 \mathrm{~g} / \mathrm{dL}$ ) in adolescent girls was $13.2 \%$. The results of the logistic regression analysis showed that the variables associated with anemia were poor knowledge about anemia with an adjusted odds ratio $(A O R)=11.4$ (95\%Cl: 1.6-83.1), no iron supplement consumption $(A O R=14.7 ; 95 \% C l: 1.9-109.8)$, negative body image ( $A O R=30.6$; $95 \% \mathrm{Cl}: 2.9-321.1)$, tea drinking habits while eating $(A O R=52.2$; $95 \% \mathrm{Cl}: 4.2-642.9)$ and excessive menstrual volume ( $A 0 \mathrm{R}=17.1$; 95\%Cl: 1.6-185.9).

Conclusion: Negative perceptions of body image and tea drinking habits while eating increase the risk of anemia among adolescent girls aged $15-18$ years. In addition, poor knowledge about anemia, a history of not consuming iron supplements and excessive menstrual volume can also increase the risk. These factors need to be considered when designing policies to reduce anemia among adolescent girls.
\end{abstract}

${ }^{1}$ Kesdam IX/Udayana Nursing Academy

${ }^{2}$ Department of Public Health and Preventive Medicine, Faculty of Medicine, Udayana University

*Correspondence to: Kadek Agus Dwija Putra; Kesdam IX/Udayana Nursing Academy; agusdwija@ymail.com

Keywords: anemia, adolescent girls, perception of body image, tea drinking habits

Cite this Article: Putra, K.A.D., Yuliyatni, P.C.D., Sutiari, N.K.2020. The relationship between body image and tea drinking habits with anemia among adolescent girls in Badung District, Bali, Indonesia. Public Health and Preventive Medicine Archive 8(1): 24-31. D01:10.15562/ phpma.v8i1.248

\section{INTRODUCTION}

Anemia is a serious public health problem throughout the world. ${ }^{1}$ National anemia prevalence among women in Indonesia is relatively higher than men, especially in pregnant women and adolescent girls. ${ }^{2}$ The occurrence of anemia in adolescent girls is caused by increased nutritional needs related to physical and reproductive growth. ${ }^{3}$ Globally in $2011,36.4 \%$ or 7.5 million young women aged 10-19 years are reported to have anemia, ${ }^{4}$ and in Indonesia it was reported in 2013 as $26.4 \%$ in young men and women aged $5-14$ years, and $18.4 \%$ in ages 15-24 years. ${ }^{5}$

The results of previous studies indicate that anemia is influenced by many factors including socio-demographic factors (sex, age, number of family members, ethnicity, parental education), ${ }^{6-10}$ socio-economic factors (poverty, employment, food insecurity), ${ }^{6,8,9,11}$ behavioral factors (smoking, eating patterns, physical activity, nutritional intake, vegetarianism), ${ }^{6,8,10-14}$ nutritional status (body mass index, middle upper arm circumference less than normal, obesity), ${ }^{6,14}$ reproductive history (age of menarche, menstruation, post-partum health), ${ }^{8,6,10,12}$ and parasitic infections (intestinal worms). ${ }^{12}$

Nutritional problems such as anemia or other malnutrition problems are caused by two main factors namely poor nutrition and infectious diseases. ${ }^{15}$ Anemia that occurs in adolescents can be caused by inadequate food intake, considering adolescence is still overshadowed by the desire to always appear with a proportional and slim body (body image). ${ }^{16}$ Body image perceived as an 
important issue to young women, which leads many of them to make poor nutritional decisions in order to achieve their desired weight. ${ }^{16}$ Because of such negative body image perception, teenagers often choose to limit food intake and even reduce their appetite which has affected their nutritional status. ${ }^{17}$

In addition to body image, the habits of drinking tea while eating meals is also important cause of anemia in young women. Tea inhibits iron absorption when consumed together with food/meals, so, it can cause anemia. ${ }^{18}$ Although tea has many health benefits, but it can inhibit the absorption of non-heme iron by $79-94 \%$ if consumed together with foods. ${ }^{19}$

Several studies have looked at the relationship between anemia with body image perception, and the relationship between anemia with the habit of drinking tea while eating, but these have not produced consistent results. Some reported that body image was related to anemia, ${ }^{17}$ while others reported that body image was not related to anemia. ${ }^{20}$ Similarly, with regards to the relationship between anemia and tea drinking habits, some studies showed an association between drinking tea with anemia, ${ }^{13}$ whereas other studies reported otherwise. $^{21}$

This study aims to determine the relationship between body image perception and tea drinking habits while eating with anemia among adolescent girls.

\section{METHODS}

This was an analytic cross-sectional study carried out at senior high schools in Badung Districts. Badung is one of the nine districts in Bali province, Indonesia. Geographically, Badung stretches from the South, Nusa Dua, to North, Plaga, which are both economically diverse. South Badung (urban) is a central to the tourism sector including the development of tourism destinations, while northern Badung (rural) is an agricultural, buffer and water catchment area.

Two schools were selected purposively from 44 public and private senior high schools in Badung district, namely one school representing the northern Badung area (Abiansemal 1 Senior High School) and one school representing the southern Badung area (Kuta 2 Senior High School). The total population was 1,375 students, and a sample of 106 adolescent girls aged 15-18 years was selected by systematic random, with division of 53 female students in each school. The number of samples was determined with a significance level of $95 \%$, power $80 \%$, the proportion of anemia in adolescents with positive body image $57.4 \%$ and in adolescents with negative body image as much as $42.6 \%{ }^{16}$
Data collected included: hemoglobin levels measured by hematological panel examination (hemogram) with Hematology Autoanalyzer (brand Mindray BC-2800), nutritional status based on body mass index/BMI by means of anthropometric measurements (body weight and height). Data on socio-demographics (age, number of family members, paternal education), socioeconomics (paternal occupation, family income), behavior (iron supplement consumption, breakfast habits, frequency of eating, dietary restrictions, fruit consumption, vegetable consumption, meat consumption, drinking tea while eating and dieting). Menstrual patterns (age of menarche, menstrual status, menstrual cycle, number of replacement pads per day during menstruation, duration of menstruation), history of worms' infestation (from childhood to the time of research), knowledge (about anemia), and perception of body image. These variables were collected by individual face to face interviews using a standardized questionnaire, ${ }^{13,17}$ which were conducted in each school.

Anemia status was grouped based on blood hemoglobin level, namely anemia $(\mathrm{Hb}<12 \mathrm{~g} / \mathrm{dl})$ and non-anemia $(\mathrm{Hb} \geq 12 \mathrm{~g} / \mathrm{dl}) .{ }^{22}$ Body image perception was categorized into two, positive body image perception and negative body image perception (using a Likert scale with 32 statements), ${ }^{17}$ and the habit of drinking tea (warm tea/iced tea) while eating main foods was categorized into drinking tea while eating and not drinking tea while eating (with a time limit of the past month until the time of the study). ${ }^{13}$

Data were analyzed descriptively, then, bivariate analysis using Chi-square test, and multivariate analysis using logistic regression were performed. Data were presented in the form of anemia prevalence, odds ratio, 95\% confidence interval (CI) and significant value (p). This study was approved by the Ethics Committee, Faculty of Medicine, Udayana University/Sanglah General Hospital Denpasar on April 11, 2018, Number: 851/ UN14.2.2/PD/KEP/2018.

\section{RESULTS}

Of the 106 high school students involved in the study, $13.2 \%$ had anemia. Table 1 shows that the age is normally distributed, average age $( \pm \mathrm{SD})$ was $16.37( \pm 0.68)$ years, with the majority being 16 years (46.2\%). With regards to the socio-economic status of the family, more than half $(56.6 \%)$ have permanent jobs and $66 \%$ of the family have income above the minimum wages in Badung District (IDR 2,499,900) ${ }^{23}$ with an average income of IDR $3,420,000$. From the number of family members, 
$59.4 \%$ of respondents had family members of five or above, ranging from 2-13 people with an average family size of 5.04 people and most of the respondents' father (94.3\%) completed junior high school or above.

Table 2 shows the results of anthropometric and nutritional status of adolescent girls, with an average of weight $52.37 \mathrm{~kg}$, height $156.97 \mathrm{~cm}$ and BMI 21.26 $\mathrm{kg} / \mathrm{cm} 2$. Most of the samples, $77.4 \%$, had normal nutritional status and others were categorized as abnormal/malnourished (underweight, overweight and obese). Furthermore, to illustrate eating behavior variables, most of the samples $(60.4 \%)$ had a habit of eating breakfast, frequency of complete meals three times/day (56.6\%), did not have dietary restrictions $(81.1 \%)$, reported consuming fruit $(81.5 \%)$ and vegetables $(85.5 \%)$; however, the majority $(70.8 \%)$ also said that they had the habit of drinking tea while eating. In addition, almost all samples had the habit of consuming meat dishes and were not on a diet, with percentages of $98.1 \%$ and $90.6 \%$, respectively. Nearly three-quarters of the respondents (74.5\%) also consumed iron supplements.

Most of the respondents (77.4\%) had a good level of knowledge about anemia, with an average knowledge score of 20.57, with scores ranging from 12-28. However, it was evident that knowledge is

Table 1. Sociodemographic and socioeconomic characteristics of adolescent girls in Badung District

\begin{tabular}{lcc}
\hline Variable & $\mathbf{n}$ & $\%$ \\
\hline Socio-Demographics & & \\
Age & & \\
Mean \pm & $16.3 \pm 0.7$ & \\
Min-max & $15-18$ & \\
$\quad$ 15 years & 10 & 9.4 \\
$\quad$ 16 years & 49 & 46.2 \\
$\quad$ 17 years & 45 & 42.5 \\
$\quad 18$ years & 2 & 1.9 \\
Number of family members (include parents) & & \\
$\quad \leq 5$ people & 43 & 40.6 \\
$\quad>5$ people & 63 & 59.4 \\
Paternal education & & \\
$\quad$ High (senior high school and above) & 100 & 13.2 \\
$\quad$ Low (junior high school and below) & 6 & 86.8 \\
Hemoglobin (Hb) & & \\
$\quad$ Anemia & 14 & 13.2 \\
$\quad$ No anemia & 92 & 86.8 \\
Family socio-economic status & & \\
Paternal occupation & & \\
$\quad$ Full time employment & 60 & 56.6 \\
$\quad$ Not full time employment & 46 & 43.4 \\
Family income & & \\
$\quad \geq$ Minimum wage (IDR 2,499,900) & & \\
$\quad<$ Minimum wage (IDR 2,499,900) & 70 & 66.0 \\
\hline Total & 36 & 34.0 \\
\hline
\end{tabular}

still lacking on the causes of anemia and types of foods that high in iron.

Menstrual patterns are measured based on the age of menarche, menstrual status, menstrual cycle, length of menstruation and number of pads use per day. From the analysis, it was found that almost all girls (98.1\%) experienced menarche at age $\geq 11$ years (average 12.91 years), 90.6\% were not menstruating at the time of measurement and $92.5 \%$ had an average menstrual period of $\leq 7$ days. The majority (89.6\%) of respondents had a menstrual cycle of $>28$ days (average 28.25 days) and half (50.9\%) reported changing of pads less or equal to 3 times/ day. Only a small proportion (3.8\%) of respondents had a history of helminthiasis.

From the Chi-square test as presented in Table 3 , there was no significant relationship between nutritional status and anemia. Regarding the relationship between nutritional status and anemia, 9/82 (11\%) of respondents with normal nutritional status had anemia, while among respondents with abnormal nutritional status, there were 5/24 (20.8\%) with anemia. Likewise, for eating behavior variables such as breakfast habits, frequency of eating, dietary restrictions, fruit consumption, vegetable consumption, meat consumption and dietary habits were not related to anemia in adolescent girls.

There was a significant relationship between tea drinking habits while eating and consumption of iron supplements with anemia. Almost a third, 9/31 (29\%) of respondents who had the habit of drinking tea while eating had anemia, while only $5 / 75(6.7 \%)$ of those who did not drink tea when eating had anemia. With regards to iron supplement consumption, 9/27(33.3\%) respondents who did not consume iron supplements were anemic while those who consumed iron supplements who had anemia were $5 / 79(6.3 \%)$.

From the analysis of menstrual patterns, it was found that age of menarche, menstrual status, menstrual cycle and length of menstruation did not significantly correlate with anemia in adolescent girls. As for the variable of menstrual volume (sanitary pad usage) there was a significant correlation, where $11 / 52(21.2 \%)$ adolescents who had a frequency of usage of more than 3 times/ day experienced anemia, compared to $3 / 54$ (5.6\%) of those with frequency of 3 times or less a day. There was no significant relationship between the history of helminthiasis with anemia among the respondents.

With regards to family socio-economic status including paternal education, paternal occupation, family income and number of family members were not significantly related with anemia among adolescent girls (Table 4). There was a significant 
Table 2. Nutrition status, eating behaviors, knowledge, body image perception, menstruation patterns, and intestinal worm infestation in adolescent girls

\begin{tabular}{|c|c|c|}
\hline Variable & $\mathbf{n}$ & $\%$ \\
\hline \multicolumn{3}{|l|}{ Nutritional Status } \\
\hline Underweight & 3 & 2.8 \\
\hline Normal & 82 & 77.4 \\
\hline Overweight & 18 & 17.0 \\
\hline Obese & 3 & 2.8 \\
\hline \multicolumn{3}{|l|}{ Habits } \\
\hline \multicolumn{3}{|l|}{ Breakfast habits } \\
\hline Breakfast & 64 & 60.4 \\
\hline No breakfast & 42 & 39.6 \\
\hline \multicolumn{3}{|l|}{ Eating frequency } \\
\hline$\geq 3$ times a day & 60 & 56.6 \\
\hline$<3$ times a day & 46 & 43.4 \\
\hline \multicolumn{3}{|l|}{ Fasting } \\
\hline Never & 86 & 81.1 \\
\hline Sometimes & 20 & 18.9 \\
\hline \multicolumn{3}{|l|}{ Fruit consumption } \\
\hline Yes & 97 & 81.5 \\
\hline No & 9 & 8.5 \\
\hline \multicolumn{3}{|l|}{ Vegetable consumption } \\
\hline Yes & 91 & 85.8 \\
\hline No & 15 & 14.2 \\
\hline \multicolumn{3}{|l|}{ Meat consumption } \\
\hline Yes & 104 & 98.1 \\
\hline No & 2 & 1.9 \\
\hline \multicolumn{3}{|l|}{ Diet } \\
\hline Not dieting & 96 & 90.6 \\
\hline Dieting & 10 & 9.4 \\
\hline \multicolumn{3}{|l|}{ Tea drinking during meals } \\
\hline No & 75 & 70.8 \\
\hline Yes & 31 & 29.2 \\
\hline \multicolumn{3}{|l|}{ Iron supplements } \\
\hline Yes & 79 & 74.5 \\
\hline No & 27 & 25.5 \\
\hline \multicolumn{3}{|l|}{ Knowledge about anemia } \\
\hline Good & 82 & 77.4 \\
\hline Poor & 24 & 22.6 \\
\hline \multicolumn{3}{|l|}{ Body image } \\
\hline Positive & 68 & 64.2 \\
\hline Negative & 38 & 35.8 \\
\hline \multicolumn{3}{|l|}{ Menstrual cycle } \\
\hline \multicolumn{3}{|l|}{ Age of menarche } \\
\hline$<11$ years & 2 & 1.9 \\
\hline$\geq 11$ years & 104 & 98.1 \\
\hline \multicolumn{3}{|l|}{ Menstrual status } \\
\hline Not menstruating & 96 & 90.6 \\
\hline Menstruating & 10 & 9.4 \\
\hline \multicolumn{3}{|l|}{ Cycle } \\
\hline$\leq 28$ days & 11 & 10.4 \\
\hline$>28$ days & 95 & 89.6 \\
\hline \multicolumn{3}{|c|}{ Bleeding volume (change of pads) } \\
\hline$\leq 3$ a day & 54 & 50.9 \\
\hline$>3$ a day & 52 & 49.1 \\
\hline Length of menstruation & & \\
\hline$\leq 7$ days & 98 & 92.5 \\
\hline$>7$ days & 8 & 7.5 \\
\hline History of intestinal worms & & \\
\hline No & 102 & 96.2 \\
\hline Yes & 4 & 3.8 \\
\hline Total & 106 & 100 \\
\hline
\end{tabular}

relationship between knowledge about anemia with the prevalence of anemia. A total of 6/82 (7.3\%) of knowledgeable young women experienced anemia, while among young women of poor knowledge, there were $8 / 24$ (33.3\%) who were anemic. There was also a significant relationship between perception of body image with anemia among respondents. About one third of respondents (28.9\%) who had negative body image perceptions had anemia, whilst only about $4.4 \%$ of young women who had positive body image perceptions had anemia.

Table 5 shows the factors associated with anemia in adolescent girls analyzed using logistic regression with forward stepwise (likelihood ratio) method. Of the 11 variables included in the multivariate analysis, only 5 variables showed significant association. These predictors were poor knowledge about anemia (AOR=11.4; 95\%CI: 1.6-83.1; $\mathrm{p}=0.017)$, lack of iron supplements (AOR=14.7; 95\%CI: 1.9-109.8; $\mathrm{p}=0.009)$, negative body image perception $(\mathrm{AOR}=30.6$; 95\%CI: 2.9321.1; $\mathrm{p}=0.004)$, tea drinking habits while eating (AOR=52.2; 95\%CI: 4.2-642.9; $\mathrm{p}=0.002)$, and menstrual volume (pad usage) $>3$ times/day during menstruation $\quad(\mathrm{AOR}=17.1 ; \quad 95 \% \mathrm{CI}$ : $1.6-185.9$; $\mathrm{p}=0.020$ ).

\section{DISCUSSION}

The result of this study indicates that the prevalence of anemia among adolescent girls in Badung District's High Schools is as high as $13.2 \%$, which based on WHO standards falls into the mild category, within the range of $5 \%-19.9 \% .^{24}$ This prevalence is much lower compared to a previous study in 2015, which reported the prevalence of anemia in Badung was $71.3 \%{ }^{13}$ This might be caused by differences in measurement of hemoglobin level and not all samples in this study are coming from Abiansemal High School. The previous study was using Portable Nesco tool, whereas in this study, we used complete blood examination with an autoanalyzer hematology tool which has a higher level of accuracy.

In addition, Badung District government established iron supplementation to adolescent girls to overcome this anemia problem, the program yet to implement in 2015 when the first study was conducted, while it was already running during our research in 2018, which may contribute to the reduction of anemia prevalence in this present study. This fact is supported by our results which showed that the majority of the adolescent girls take iron tablets and that the consumption of iron supplements was associated with a reduction in probability of being anemic. Young women who did not take iron supplements had a 14.7 times 
tendency to suffer from anemia compared to those who did. This is in line with another study which shows that the provision of long-term weekly ironfolate supplementation is a practical, safe, effective, and inexpensive method for improving iron nutrition in young women. ${ }^{25}$

Table 3. Relationship between nutritional status, behavior, menstruation patterns, and intestinal worm history and anemia among adolescent girls

\begin{tabular}{|c|c|c|c|}
\hline Variable & $\begin{array}{c}\text { Anemia } \\
\text { n (\%) }\end{array}$ & $\begin{array}{c}\text { No anemia } \\
\mathrm{n}(\%)\end{array}$ & $\mathbf{p}$ \\
\hline \multicolumn{4}{|l|}{ Nutritional status } \\
\hline Abnormal & $5(20.8)$ & $19(79.2)$ & 0.301 \\
\hline Normal & $9(11.0)$ & $73(89.0)$ & \\
\hline \multicolumn{4}{|l|}{ Eating habits } \\
\hline \multicolumn{4}{|l|}{ Breakfast habits } \\
\hline No breakfast & $3(7.1)$ & 39 (92.9) & 0.156 \\
\hline Breakfast & $11(17.2)$ & $53(82.8)$ & \\
\hline \multicolumn{4}{|l|}{ Eating frequency } \\
\hline$<3$ times a day & $6(13.0)$ & $40(87.0)$ & 1.000 \\
\hline$\geq 3$ times a day & $8(13.3)$ & $52(86.7)$ & \\
\hline \multicolumn{4}{|l|}{ Fasting } \\
\hline Sometimes & $5(25.0)$ & $15(75.0)$ & 0.134 \\
\hline Never & $9(10.5)$ & $77(89.5)$ & \\
\hline \multicolumn{4}{|l|}{ Fruit consumption } \\
\hline No & $2(22.2)$ & $7(77.8)$ & 0.339 \\
\hline Yes & $12(12.4)$ & $85(87.6)$ & \\
\hline \multicolumn{4}{|l|}{ Vegetable consumption } \\
\hline No & $3(20.0)$ & $12(80.0)$ & 0.415 \\
\hline Yes & $11(12.1)$ & $80(87.9)$ & \\
\hline \multicolumn{4}{|l|}{ Meat consumption } \\
\hline No & $1(50.0)$ & $1(50.0)$ & 0.248 \\
\hline Yes & $13(12.5)$ & $91(87.5)$ & \\
\hline \multicolumn{4}{|l|}{ Dieting } \\
\hline Dieting & $1(10.0)$ & $9(90.0)$ & 1.000 \\
\hline Not dieting & $13(13.5)$ & $83(86.5)$ & \\
\hline \multicolumn{4}{|l|}{ Tea drinking during meals } \\
\hline Yes & $9(29.0)$ & $22(71.0)$ & 0.004 \\
\hline No & $5(6.7)$ & $70(93.3)$ & \\
\hline \multicolumn{4}{|l|}{ Iron supplements } \\
\hline No & $9(33.3)$ & $18(66.7)$ & 0.001 \\
\hline Yes & $5(6.3)$ & $74(68.6)$ & \\
\hline \multicolumn{4}{|l|}{ Menstrual cycle } \\
\hline \multicolumn{4}{|l|}{ Age of menarche } \\
\hline$\geq 11$ years & $13(12.5)$ & $91(87.5)$ & 0.248 \\
\hline$<11$ years & $1(50.0)$ & $1(50.0)$ & \\
\hline \multicolumn{4}{|l|}{ Menstrual status } \\
\hline Menstruating & $3(30.0)$ & $7(70.0)$ & 0.126 \\
\hline Not menstruating & $11(11.5)$ & $85(88.5)$ & \\
\hline \multicolumn{4}{|l|}{ Cycle } \\
\hline$>28$ days & $12(12.6)$ & $83(87.4)$ & 0.637 \\
\hline$\leq 28$ days & $2(18.2)$ & $9(81.8)$ & \\
\hline \multicolumn{4}{|c|}{ Bleeding volume (change of pads) } \\
\hline$>3$ times a day & $11(21.2)$ & $41(78.8)$ & 0.022 \\
\hline$\leq 3$ times a day & $3(5.6)$ & $51(94.4)$ & \\
\hline \multicolumn{4}{|l|}{ Length of menstruation } \\
\hline$>7$ days & $1(12.5)$ & $7(87.5)$ & 1.000 \\
\hline$\leq 7$ days & $13(13.3)$ & $85(86.7)$ & \\
\hline \multicolumn{4}{|c|}{ History of intestinal worms } \\
\hline Yes & $1(25.0)$ & $3(75.0)$ & 0.438 \\
\hline No & $13(12.7)$ & $89(87.3)$ & \\
\hline
\end{tabular}

Our study found a significant relationship between perceptions of body image and anemia in young women. This result is in line with a previous study in Makassar which indicated a relationship between body image and $\mathrm{Hb}$ levels in young women, where those who are anemic tend to have a negative body image. It was also found that there was a positive relationship between body image and dietary behavior among young women in Makassar, where those who had a positive body image had a healthy diet. ${ }^{16}$ Negative body image can often have health impacts such as overuse of laxatives, vomiting of food, strenuous physical activity, and unhealthy behavior/eating patterns due to inappropriate weight control. ${ }^{26}$

Body image is personal perception that is viewed as important for most young women. Some of them usually do anything to keep their body shape slim including restrictions on food intake and weight control that can be dangerous. ${ }^{16}$ Studies showed that overweight young women tend to have a negative body image, whereas non-overweight adolescent girls more likely to have a positive body image. ${ }^{27}$ Adolescents who have positive eating behaviors and body image tend to have better nutritional status compared to adolescents who have poor eating behaviors and negative body image. ${ }^{28}$ Poor interpretation and perception of bodily changes during the adolescent years can also influence exercise frequency and food choices. ${ }^{27}$

Meanwhile, the habit of drinking tea while eating was also associated with anemia among adolescent girls. This finding supported by previous study among young women in Gunungsari which found that there was a correlation between the consumption patterns of $\mathrm{Fe}$ inhibitors (caffeine, tannins, oxalates, phytate) found in soybeans, tea, and coffee, with the status of anemia among female students. ${ }^{18}$ Habits of consuming foods that can interfere with the absorption of iron (such as coffee and tea) together at mealtime, causes iron absorption to be lower. ${ }^{29}$ Consumption of one cup of tea a day can reduce iron absorption by $49 \%$ in people with iron deficiency anemia, while consumption of two cups of tea a day decreases absorption by $67 \%{ }^{18}$ Tea consumed up to one hour after meals would reduce the absorption capacity of red blood cells to iron by $64 \%$ and therefore it is recommended to consume tea at least two hours after meals. ${ }^{18}$

On the other hand, adolescent's knowledge about anemia was a protective factor for the risk of anemia in adolescent girls. The girls who have poor knowledge about anemia have more than ten folds tendency to have anemia compared to those with good knowledge about anemia. This is in line with other studies wherein respondents with 
Table 4. Relationship between family socio-economic status, knowledge and body image perception with anemia among adolescent girls

\begin{tabular}{|c|c|c|c|}
\hline Variable & $\begin{array}{c}\text { Anemia } \\
\text { n (\%) }\end{array}$ & $\begin{array}{c}\text { No anemia } \\
\mathrm{n}(\%) \\
\end{array}$ & $\mathbf{p}$ \\
\hline \multicolumn{4}{|l|}{ Family socio-economic status } \\
\hline \multicolumn{4}{|l|}{ Paternal education } \\
\hline Low & $2(33.3)$ & $4(66.7)$ & 0.178 \\
\hline High & $12(12.0)$ & $88(88.0)$ & \\
\hline \multicolumn{4}{|l|}{ Paternal occupation } \\
\hline Not full time employment & $5(10.9)$ & $41(89.1)$ & 0.578 \\
\hline Full time employment & $9(15.0)$ & $51(85.0)$ & \\
\hline \multicolumn{4}{|l|}{ Family Income } \\
\hline$<$ Average Wage & $4(12.7)$ & $32(87.3)$ & 0.768 \\
\hline$\geq$ Average Wage & $10(14.0)$ & $60(86.0)$ & \\
\hline \multicolumn{4}{|l|}{ Number of Family Members } \\
\hline$>5$ people & $8(8.3)$ & $55(54.7)$ & 1.000 \\
\hline$\leq 5$ people & $6(5.7)$ & $37(37.3)$ & \\
\hline \multicolumn{4}{|l|}{ Knowledge about anemia } \\
\hline Poor & $8(33.3)$ & $16(66.7)$ & 0.003 \\
\hline Good & $6(7.3)$ & $76(92.7)$ & \\
\hline \multicolumn{4}{|l|}{ Body image } \\
\hline Negative & $11(28.9)$ & $27(71.1)$ & 0.001 \\
\hline Positive & $3(4.4)$ & $65(95.6)$ & \\
\hline
\end{tabular}

Table 5. Adjusted odds ratio (AOR) determinants of anemia among adolescent girls

\begin{tabular}{lccc}
\hline Variable & AOR & $\mathbf{9 5 \% C I}$ & $\mathbf{p}$ \\
\hline Knowledge about anemia & & & \\
$\quad$ Good & $1($ Ref) & & \\
$\quad$ Poor & 11.4 & $1.6-83.1$ & 0.017 \\
Iron supplements & & & \\
$\quad$ Yes & $1($ Ref) & & \\
$\quad$ No & 14.7 & $1.9-109.8$ & 0.009 \\
Body image & & & \\
$\quad$ Positive & $1($ Ref) & & \\
$\quad$ Negative & 30.6 & $2.9-321.1$ & 0.004 \\
$\quad$ Tea drinking during meals & & & \\
$\quad$ No & $1($ Ref) & & \\
$\quad$ Yes & 52.2 & $4.2-642.9$ & 0.002 \\
Bleeding volume (change of pads) & & & \\
$\quad \leq 3$ times a day & $1($ Ref) & & \\
$\quad>3$ times a day & 17.1 & $1.6-185.9$ & 0.020 \\
\hline
\end{tabular}

poor knowledge about anemia have higher chance to suffer from anemia compared to respondents who have a good level of knowledge. ${ }^{30}$ Adequate knowledge about anemia is related to good eating behaviors, supported by our analysis of knowledge variables and dietary variables. Teenagers who consumed fruit, vegetables and meat dishes mostly had good knowledge about anemia with a percentage of $77.3 \%, 79.1 \%$ and $77.9 \%$, respectively. Likewise, among the young women who did not drink tea while eating, most had good knowledge about anemia. This finding signifies that knowledge about anemia influences adolescent girls' decisions on the food consumption, so the efforts to improve adolescent knowledge about anemia and healthy eating patterns should be continued and upscaled.

Furthermore, we found that menstrual volume (pad replacement) was significantly associated with anemia in the adolescent girls. Girls who changed pads more than three times/day during menstruation had a tendency of 17 times to suffer from anemia compared to those who used fewer pads per day. The frequency of changing pads is a proxy of higher volume of blood loss during menstruation. This means that those with higher volume of blood loss are more at risk of anemia than those with less bleeding during menstruation. The average blood loss during menstruation is about $30 \mathrm{ml} /$ day which is equal to additional need of $0.5 \mathrm{mg}$ of iron per day. Daily blood loss is calculated from the iron content in blood lost during menstruation for a period of one month. About $10 \%$ of women will lose as much as $80 \mathrm{ml}$ of blood which is equivalent to $1 \mathrm{mg}$ of iron per day. By taking this higher value of $1 \mathrm{mg} /$ day, total iron loss (basal loss plus menstruation) in a woman will be $30 \mu \mathrm{g} / \mathrm{kg}$ body weight $/$ day (>1.5 mg/day). Women would not be able to maintain a positive iron balance if her iron needs are based on an average loss of $30 \mathrm{ml}$ blood during menstruation. ${ }^{31}$ Other menstrual pattern variables are not related to anemia among adolescent girls. This is in line with another study which state that there is no relationship between menstrual patterns and anemia $(\mathrm{r}=0.031 ; \mathrm{p}=0.789) .{ }^{32}$

Based on our findings, we recommend policy makers to develop an education program for girls at school age, regarding anemia including the importance of consuming iron supplements, healthy food consumption and other eating habits that may increase chance of anemia such as consuming tea while eating. It is also necessary to provide adequate information regarding body image perception, and reproductive health education.

This study has several limitations. The study was conducted among adolescent girls in high school setting, so its generalization may be limited to those settings with similar characteristics. The samples were selected only from two high schools, again we must be cautious when generalizing the finding. Regarding the menstrual volume, we can only estimate bleeding from the frequency of sanitary pads changes, which may not be the best indicator of blood loss.

\section{CONCLUSION}

The prevalence of anemia among adolescent girls in Badung District was 13.2\%, much lower than previous study suggesting the current anemia prevention program may have a positive impact. 
Our study shows relationship between negative body image perception and the habit of drinking tea while eating with risk of anemia among adolescence girls. We also found that poor knowledge about anemia, inadequate consumption of iron supplements and excessive menstrual volume can also increase the risk of anemia.

The iron supplementation program among high school students established by Badung District government has a positive impact on reducing the prevalence of anemia, hence it should be maintained and upscaled. It is also necessary to introduce a comprehensive measure to increase knowledge of adolescent girls on good eating patterns and a campaign to build positive body image perception.

\section{ACKNOWLEDGEMENTS}

We would like to thank Bali Provincial Health Laboratory, Abiansemal 1 Senior High School, Kuta 2 Senior High School and all high school students who helped us in completing this study.

\section{AUTHOR CONTRIBUTION}

DP designed and conceived the study, collected and analysed the data, wrote the first draft of the manuscript and edited the manuscript; NKS was involved in the design and conception of the study, supported the analysis, provided feedback and edited the manuscript; $\mathbf{C D}$ critically reviewed the study proposal, conducted data management, and edited the manuscript.

\section{CONFLICT OF INTEREST}

None declared (There is no conflict of interest)

\section{FUNDING}

The study was funded by Kesdam IX/Udayana Health Institute, grant No. PTB/ 273/ V/ 2016

\section{REFERENCES}

1. Priyanto LD. The relationship of age, educational background, and physical activity on female students with anemia. J Berk Epidemiol. 2018;6(2):139.

2. Putri PH, Sulistiyono A, Mahmudah M. Analisis faktor yang mempengaruhi anemia pada kehamilan usia remaja [Analysis of factors influencing anemia in adolescence pregnancy]. Maj Obstet Ginekol. 2015;23(1):33.

3. Denistikasari R. Hubungan antara asupan protein, zat besi $(\mathrm{Fe})$ dan vitamin $\mathrm{C}$ dengan kejadian anemia pada siswi SMK Penerbangan Bina Dhirgantara Karanganyar (Skripsi) [The association between protein, $\mathrm{Fe}$ and vitamin $\mathrm{C}$ intake with anemia among female students at Bina Dhirgantara Aviation High School (Undergraduate Thesis)]. Muhammadiyah Surakarta; 2016.

4. World Health Organization. Prevention of iron deficiency anaemia in adolescents role of weekly iron. Regional office for South-East Asia: World Health Organization; 2011

5. Ministry of Health of The Republic of Indonesia. Riset Kesehatan Dasar (RISKESDAS) 2013 [The 2013 Indonesia Basic Health Research]. 2013;1-384.

6. Killip S, Bennett JM, Chambers MD. Iron deficiency anemia. Am Fam Physician. 2007;75(5):671-678.

7. Nead KG, Halterman JS, Kaczorowski JM, Auinger P, Weitzman M. Overweight children and adolescents: A risk group for iron deficiency. Pediatrics. 2004;114(1):104-114.

8. Deepa LS, Laura EMK, Allen RK, Carol SW, Lan MP. Differences in risk factors for anemia between adolescent and adult women. J Women's Heal. 2016;25(5):505-513.

9. Tesfaye M, Yemane T, Adisu W, Asres Y, Gedefaw L. Anemia and iron deficiency among school adolescents: Burden, severity and determinant factors in Southwest Ethiopia. Adolescent Health, Medicine and Therapeutics. 2015;6: 189-196.

10. Arumsari E. Faktor risiko anemia pada remaja putri peserta Program Pencegahan dan Penanggulangan Anemia Gizi Besi (PPAGB) di Kota Bekasi (Skripsi) [Risk factors of anemia among adolescent girls who participating in Fe Deficiency Anemia Prevention and Control Program in Bekasi City (Undergraduate Thesis)]. Institut Pertanian Bogor; 2008.

11. Balci YI, Karabulut A, Gurses D, Covut IE. Prevalence and risk factors of anemia among adolescents in Denizli, Turkey. Iran J Pediatr. 2012;22(1):77-81.

12. Kaur S, Deshmukh P, Garg B. Epidemiological correlates of nutritional anemia in adolescent girls of Rural Wardha. Indian J Comunity Med. 2006;31(4):255-257.

13. Febianingsih NPE, Indriani C, Pujana W, Putra D, Putra Y. Epidemiological determinants of anemia among adolescent girls of Abiansemal High School, Badung District, Bali Province, 2015. In: The 8th TEPHINET Bi-regional Scientific Conference. Siem Reap, Cambodia; 2016. p. 122.

14. Ahankari A, Myles P, Fogarty A, Dixit J, Tata L. Prevalence of iron-deficiency anaemia and risk factors in 1010 adolescent girls from rural Maharashtra, India: a crosssectional survey. Public Health. 2017;142:159-66.

15. Ministry of Health of The Republic of Indonesia. Kenali masalah gizi yang ancam remaja Indonesia [Identify the potential nutrition problems among adolescents in Indonesia]. Ministry of Health of The Republic of Indonesia. 2019. p. 8-9.

16. Amalia $\mathrm{M}$, Indriasari $\mathrm{R}$, Jafar $\mathrm{N}$. Hubungan body image dengan perilaku diet dan kadar $\mathrm{Hb}$ remaja putri di SMAN 10 Kota Makassar [The association between body image with dieting behavior and $\mathrm{Hb}$ level among adolescent girls at Makassar City 10th Senior High School]. Universitas Hasanuddin; 2014.

17. Masita. Hubungan citra tubuh dengan kejadian anemia pada remaja di Kabupaten Purworejo (Tesis) [The association between body image and anemia among teenagers in Purworejo District (Thesis)]. Universitas Gadjah Mada; 2008.

18. Masthalina H, Laraeni Y, Dahlia YP. Pola konsumsi (faktor inhibitor dan enhancer $\mathrm{Fe}$ ) terhadap status anemia remaja putri [Consumption pattern (Fe inhibitors and enhancers) towards anemia status of adolescent girls. J Kesehat Masy. 2015;11(1):80-86.

19. Hurrell R, Reddy M, Cook J. Inhibiton of nonhaem iron absorpton in man by polyphenolic containing beverages. Br J Nutr. 1999;81:289-95.

20. Sari HP, Dardjito E, Anandari D. Iron deficiency anemia among adolescent in Banyumas. J Kesmas Indones. 2016;8(1):16-31.

21. Kalsum U, Halim R. Kebiasaan sarapan pagi berhubungan dengan kejadian anemia pada remaja di SMA Negeri 8 Muaro Jambi [The habit of having breakfast is associated 
with anemia among teenagers at Muaro Jambi $8^{\text {th }}$ Senior High School]. J Penelit Univ Jambi Seri Sains. 2016;18(1):919.

22. World Health Organization. The management of nutrition in major emergencies. Geneva: World Health Organization; 2010. p. 18.

23. Governor of The Province of Bali. Peraturan Gubernur Bali No.65 Tahun 2017 tentang Upah Minimum Kabupaten/ Kota (The Bali Provinces Governor Act No. 65 year 2017 on the local district/city minimum wages). 2017.

24. World Health Organization. Haemoglobin concentration for the diagnosis of anemia and assessment of severity. Geneva; 2011.

25. Tee E, Kandiah M, Awin N, Chong S, Satgunasingam N, Kamarudin L, et al. School-administered weekly ironfolate supplements improve hemoglobin and ferritin concentrations in Malaysian adolescent girls. Am J Clin Nutr. 1999;69(6):1249-1256.

26. Valter PN. Body image in different periods of adolescence. Rev Paul Pediatr. 2014;32(1):63-69.

27. Wati DK, Sumarmi S. Citra tubuh pada remaja perempuan gemuk dan tidak gemuk: Studi cross sectional [Body image among overweight and non overweight adolescent girls: a cross sectional study]. Amerta Nutr. 2017:398-405.

28. Yusintha AN. Hubungan antara perilaku makan dan citra tubuh dengan status gizi remaja putri usia 15-18 tahun
[The association between eating behavior and body image with nutritional status of adolescent girls ages $15-18$ years]. Amerta Nutr. 2018;2:147-54.

29. Arisman. Buku Ajar Ilmu Gizi "Gizi dalam daur kehidupan” [Nutrition Teaching Book: Nutrition in a life cycle]. Jakarta: EGC; 2009. 75-85 p.

30. Anggraini L, Husaini, Khairiati L. The correlation of menstrual pattern and knowledge level about anemia. Berk Kesehat Masy Indones [Internet]. 2017;62. Available from: www.fk.jtam.unlam.ac.id/index.php/bkm/article/ view/ 143

31. Citrakesumasari. Anemia gizi masalah dan pencegahannya [Anemia: problem and the prevention]. 1st ed. Yogyakarta: Kalika; 2012. 6-19 p.

32. Kirana DP. Hubungan asupan zat gizi dan pola menstruasi dengan kejadian anemia pada remaja putri di SMAN 2 Semarang (Skripsi) [The association between nutrition intake and menstruation pattern with anemia among adolescent girls at Semarang $2^{\text {nd }}$ Senior High School (Undergraduate thesis)]. Universitas Diponegoro; 2011.

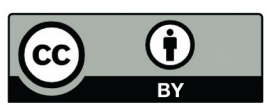

This work is licensed under a Creative Commons Attribution 